\title{
MOTOR BIOFUEL-POWERED CHP PLANTS - A STEP TOWARDS SUSTAINABLE DEVELOPMENT OF RURAL LITHUANIA
}

\author{
Laurencas Raslavičius ${ }^{1}$, Anicetas Strakšas ${ }^{2}$
}

\author{
${ }^{1}$ UAB “Axis Technologies", Kulautuvos g. 45a, 47190 Kaunas, Lithuania \\ ${ }^{2}$ Lithuanian University of Agriculture, Institute of Agro-Engineering, \\ Instituto g. 20, 54132 Raudondvaris, Kaunas region, Lithuania \\ E-mails: ${ }^{1}$ Laurencas.Raslavicius@gmail.com (corresponding author); ${ }^{2}$ Anicetas.Straksas@lzuu.lt
}

Received 27 May 2010; accepted 27 January 2011

\begin{abstract}
This paper focuses on the benefits that can be attained from the correct option of smallscale combined heat and power plant (CHP) relative to fuel availability and sphere of application. The analysis serves as a means of highlighting some of the owners of large-scale farms as well as holders of industrial greenhouses that influence the penetration of small-scale cogeneration plants running on bio-based liquid fuels. The identification of the main influencing factors and their weight is the first step towards the implementation of a more coherent strategy, if the EC (European Commission) and national energy authorities wish for new small-scale cogeneration technologies to have a future in the context of sustainable development of rural Lithuania. Against this background, this paper aims at presenting the technical, environmental and economic aspects of the possibilities of utilizing biodiesel, biodiesel-conventional diesel blends and rapeseed oil in combined heat and power production as an issue for further discussions regarding the formative breakthrough attitude towards a possible path of country's sustainable development.
\end{abstract}

Keywords: motor biofuels, cogeneration CHP plant, rural Lithuania, combined heat and power, first generation biofuels, energy supplies.

Reference to this paper should be made as follows: Raslavičius, L.; Strakšas, A. 2011. Motor biofuelpowered CHP plants - a step towards sustainable development of rural Lithuania, Technological and Economic Development of Economy 17(1): 189-205.

JEL Classification: Q16, Q27, Q41, Q42, R11.

\section{Introduction}

Sustainable global demand for fossil material continues. In light of environmental concern, as well as unease over fluctuating prices due to supply and global events, the search for sustainable alternatives are being explored. Use of fossil resources for electricity and heat, transportation fuels and chemical raw materials represent the major areas of use. 
In Lithuania approx. $45 \%$ of households are connected to district heating systems, which is approx. $60 \%$ of the national heat demand in accordance to final consumption. Meanwhile, the share of small scale CHP is very small as the main electricity supply came from relatively cheap nuclear power (NPP) providing approx. 80\% of the national demand (Rasburskis et al. 2006). After the de-commissioning of NPP, Lithuanian energy system has a substantial fuel saving potential by implementing CHP technologies. Thus, the revised National Energy Strategy in 2002 stresses the promotion of CHP technologies in district heating sector. However, the optimal CHP capacities in order to ensure sustainable and reliable energy generation are still very uncertain (Rasburskis et al. 2006).

CHP systems need a balanced relationship between the thermal energy supplied and the electric power produced that depends on the type of CHP system being used (CEERE 2009; Agarwal and Wong 1996; Schneider 2006; Kaltschmitt et al. 2007; Sörensen 2004). Due to different renewable electricity policies within the EU member states, CHP technology characteristics must be selected for each country or region individually (Goebel et al. 1998). In this case, Lithuania is not an exception (Raslavičius and Strakšas 2010). It is also normally important to have thermal loads that are coincidental with the electrical load to make CHP cost effective. The use of thermal energy storage is not typically economic unless the electrical rate structure has a heavy demand charge. Hence, most CHP facilities use the thermal energy at the time it is produced and so thermal energy demand should match the time that electrical energy is needed. A facility can be designed to match either the thermal or electrical load of the facility. If a facility is designed to meet the thermal load, the difference between the electrical power produced by the CHP system and the power required by the facility must either be sold to others or purchased from the grid. Conversely, if the facility is designed to meet the electrical load, energy to meet the thermal load will either need to be supplemented or disposed of (CEERE 2009). CHP technology should be considered in geographical areas where prices for electricity are high, fuel costs are low, and for applications with a requirement for both electricity and thermal energy (CEERE 2009; Raslavičius and Strakšas 2010; Schneider 2006).

\section{CHP focus on motor biofuels}

From a general consideration of sustainability, it would be natural for Lithuanian agriculture to contribute a significant part of the country's energy supply and to have a positive energy balance. Today, agriculture has gross energy consumption, which in fact is more than twice the existing energy production from agricultural biomass (Bugge 2001). Oppositely, it seems unnatural if agriculture can only be carried on with an effective consumption of fossil energy, in other words with a negative balance. However, this is presently the case. Motor biofuels such as biodiesel and rapeseed oil are the most versatile fuels because they can easily be used for heat production, CHP and mobile purposes (Bugge 2001).

It is important for farmers, entrepreneurs and government to identify and evaluate crops that can be profitable and can be cultivated and converted into value-added products for consumers and industry (Agarwal and Wong 1996). One crop that is highly valued in Lithuania is rapeseed. Demand for rapeseed is growing worldwide; EU-27 countries are consuming more than they can produce. 
A number of farmers in Lithuania have expressed a willingness to grow rapeseed. However, there is substantial potential for it to grow but cultivation and processing must be coordinated correctly and cooperatively. Lithuania's rapeseed yield of about 2.0 tones per hectare (tph) is good compared with $2.47 \mathrm{tph}$ in Poland, $2.73 \mathrm{tph}$ in EC and 1.21 tph in Canada (Agarwal and Wong 1996).

Depending on the current situation (year: 2010), an availability of renewable resources for motor biofuels generation, been utilized in cogeneration output cycle has been valuated, putting a special emphasis on rapeseed crop explore in Lithuania as well as spheres of application and untapped opportunities for CHP plants, very much depended on heat demand and competitive ability to fossil fuels. Valuation also includes analysis of the balance for the different steps of rapeseed oil production in rural Lithuania.

\subsection{Rapeseed crop exploration for major regions of Lithuania}

The development of renewable energy sources (RES) for motor biofuels can provide impetus to agriculture and rural areas of Lithuania (Liubarskis and Raslavičius 2003). It can create new markets for agricultural products (for energy generation instead of, or coupled with food production), and it could present an attractive decentralized energy delivering solutions for rural communities.

Efficiency of most renewable energy technologies is site-specific (Raslavičius and Strakšas 2010). Thus, detailed information on available resources and their relative economics is very important for their successful development. RES in Lithuania are fairly well studied and reported, but the economic potential of them is quite difficult to determine. It is obvious that only a portion of the technical potential can be realistically met. Moreover, the estimates of technical and economic potential are only indicative and are likely to change over time. The technical potential will likely grow with the development of available technologies. The economic potential of RES in the medium and long term will very much depend on their cost compared to prices for fossil fuels.

It is expected that rapeseed in rural Lithuania will play a significant role in providing future renewable feedstock for the different energy conversion routes (heat, electricity, liquid biofuel, etc.). While rapeseed crops may create an economically attractive to growing crops for conventional food in Lithuania, the presented research activity also focused on assessing availability of agricultural land (see Fig. 1).

The availability of agricultural land for rapeseed crops is highest in Joniškis (13819 ha), Panevėžys (12688 ha), Šakiai (11862 ha), Kèdainiai (11802) and Šiauliai (11745 ha) regions.

In recent years rapeseed prices have been extremely low, what means low profits or losses for farmers. In this case, potential energy producers are often hesitant to invest capital to build cogeneration facilities, particularly those that rely on new technologies. Land productivity (producing more rapeseed yield per hectare), as well as crop quality (producing crops that have higher oil content) are also very important factors, which can be increased via plant improvement through modern breeding technique and biotechnology.

This chapter puts a special emphasis that relationship exists between energy contribution to the attainment of rural development and rural energy use patterns. These initiatives are 


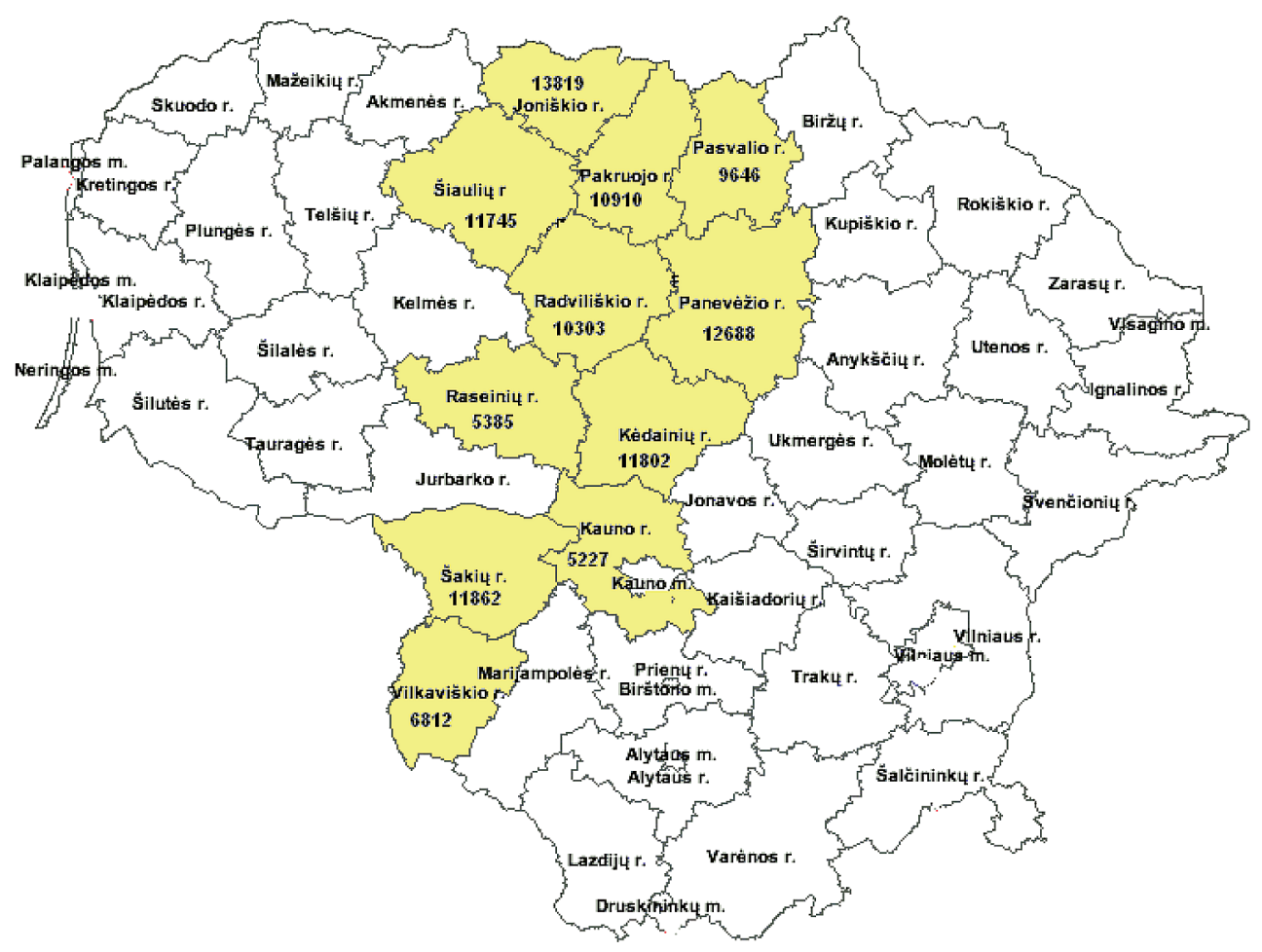

Fig. 1. Disposition of large-scale rapeseed crop (area in ha) subjected to regions of Lithuania (Department of Statistics 2008)

driven by the need to enhance rural quality of life through the introduction of renewable energy production activities that support improvement in employment and solves variety of issues related to environmental protection and country's energy independence.

\subsection{Untapped opportunity for CHP-based thermal energy in the greenhouse business}

For many growers, the most difficult task when trying to create energy-efficient greenhouse environment is determining costs per growing area and then making informed decisions on what heating equipment can help reduce energy costs. Heating a greenhouse is a huge investment and cannot be taken lightly.

Different renewable energy sources can be used for greenhouse heating (Von Zabeltitz 1994). A well-designed and operated cogeneration scheme will always provide better energy efficiency than a conventional plant, leading to both energy and cost savings. Cost savings depend on both the cost of primary energy fuel and the price of electricity that the scheme avoids. However, although the profitability of a cogeneration project generally results from its cheap electricity, its success depends on using recovered heat productively, so a prime criterion is a suitable heat requirement (UNEP 2008). 
In Lithuania, greenhouse cultivation of vegetable crops is an economically important branch of horticulture. The area of glasshouses is 70 ha and plastic greenhouses - about 600 ha (Surviliene 2001). There are 60 ha of renovated greenhouses with most advanced vegetable and flower cultivation technologies. The rest of the greenhouses are operated seasonally and do not perform their main function - to supply vegetables during winter early spring seasons. Due to economic constraints and limited financial means, some of the producers cannot afford to use rationally and full capacity glasshouses. Greenhouse tomatoes and cucumbers are the main crops, grown in approximately equal ratio. They are grown in different periods (Table 1).

Table 1. Growing periods for the greenhouse tomatoes and cucumbers (Survilienè 2001)

\begin{tabular}{llll}
\hline \multicolumn{1}{c}{ Crops } & \multicolumn{2}{c}{ Greenhouse type } & \multicolumn{1}{c}{ Cultivation cycle (months) } \\
\hline \multirow{2}{*}{ Tomato } & Under glass & Heating & XII-XI \\
\cline { 2 - 4 } & Under glass & Heating & II-III-IX \\
\hline \multirow{2}{*}{ Cucumber } & Under glass & Heating & XII-VI; VII-X \\
\cline { 2 - 4 } & Under glass & Heating & III-IV-VIII \\
\hline
\end{tabular}

Space heating is the major thermal energy use in greenhouse structures all-year-round. A significant amount of heating energy required could be supplied in the final output cycle by diesel engine running on oxygenated motor fuels. Power for lighting and fan motors are the other energy use needs. Citing Giniger and Mears (1984), the optimum matching of the unit's capacity and operating time to the heat and electrical demands of a greenhouse facility are necessary if the most economical possible use is to be made of the unit. Traditionally, from the energy conservations point of view, the greenhouse is divided into three zones needed for thermal energy: plants under thermal blanket, space under ceiling and space between roof and ceiling (Ghosal and Tiwari 2004).

The major constraint on cogenerators using liquid biofuels for the diesel engines relates the useful energy produced by the system to the fuel energy consumed. Specifically, the ratio of the sum of the total annual electrical energy produced $\left(\mathrm{E}_{p}\right)$ and one-half the useful thermal energy used in the greenhouse $\left(\mathrm{E}_{t}\right)$ to the total annual fuel energy consumed by the engine $\left(\mathrm{E}_{f}\right)$ must be equal to or greater than 0.425: $\left(\mathrm{E}_{p}+0.5 \mathrm{E}_{t}\right) / \mathrm{E}_{f} \geq 0.425$ (Jenkins 1985). This constraint limits the size of the engine that can be used and requires careful matching of the thermal demand in the greenhouse and the electrical production of the generator. According Garcia et al. (1998), cogeneration systems intended for greenhouse heating were found to have the best possibilities, especially in northern European countries, because of electricity/fuel price ratio.

Rising fuel costs may make burning of alternative liquid fuels a viable option for some greenhouse operators. Careful consideration of the information provided above is necessary to determine if alternative motor fuels will work for cost-versus-benefit scenario. 


\section{Experimental investigation, materials and methods}

The study presented has been performed based on evaluation of motor biofuel-to-CHP technology, under the specific conditions in Lithuania. For the technical-ecological description of the proposed technology the research activity involved following tasks: establishment of physical properties for the input biofuels as well as evaluation of diesel engine exploitation parameters and their impact on pollutant formation. Investment-based activity involves detailed estimation of the three most important determinants of economic profitability: electricity and heat load demands, characteristics and size of the proposed CHP plant, and the electricity tariff conditions. The economic calculations have been performed according guideline, distinguishing between heat, electricity and total energy generation costs.

It is expected, that the reduction potential of exploitation costs related to the useful heat utilization and argued selection of the biofuel type (the production of which, preferably, must be integrated into different steps of the agro-industrial chain) can most probably make a break-through in the development of Lithuania's decentralized energy sector.

\subsection{Fuel input properties}

Two types of bio-based substitutes for conventional diesel, and biodiesel blends (B50/dB50) were used as test fuels, afterwards briefly comparing them to pure diesel. Specifications for tested fuels are shown in Table 2:

- Diesel fuel (DF) / dyed diesel fuel (dDF) according to LST EN 590:2009 requirements;

- Rapeseed oil methyl ester (hereinafter - biodiesel; RME; B100) according to LST EN 14214:2009 requirements;

- Rapeseed oil (RO);

- B50/dB50 biodiesel blends.

A pruned nomenclature of motor fuel blends B50/dB50 means what percentage of biodiesel (rapeseed oil methyl ester) is actually in the fuel, the rest is fossil diesel.

Table 2. Properties of the tested motor fuels

\begin{tabular}{lcccc}
\hline \multicolumn{1}{c}{ Motor fuel } & $\begin{array}{c}\text { Relative density, } \\
\mathbf{~} \mathbf{k g} / \mathbf{c m}^{\mathbf{3}}\end{array}$ & $\begin{array}{c}\text { Higher calorific value, } \\
\mathbf{M J} / \mathbf{k g}\end{array}$ & $\begin{array}{c}\text { Viscosity at } \mathbf{4 0} \\
\mathbf{m m}^{\mathbf{2}} \mathbf{/ s}\end{array}$ & Cetane number \\
\hline $\mathrm{DF} / \mathrm{dDF}$ & 844 & 45.23 & 4.5 & 51.0 \\
\hline B100 (RME) & 884 & 40.15 & 4.7 & 55.6 \\
\hline RO (unheated) & 917 & 39.08 & 38.0 & 39.0 \\
\hline B50/dB50 & 872 & 41.32 & 4.6 & 53.3 \\
\hline
\end{tabular}

In terms of physical properties, biodiesel (B100; B50/dB50) and rapeseed oil are denser, more viscous (especially RO), and have lower calorific values compared to diesel fuel. However, these shortages anyhow do not prevent their wide application in internal combustion engines. 


\subsection{Description of the test facility}

\subsubsection{Engine test bench}

The test bench (Fig. 2) is composed of a 4.2L T40M tractor diesel engine D-144 with mechanical power of $37 \mathrm{~kW}$ at $1600 \mathrm{rpm}$, coupled with an asynchronous generator AKB-82-4UZ of $55 \mathrm{~kW}$. Specifications for the natural aspirated, direct injection, four-cylinder engine are as follows: bore/stroke - 105/120 mm; compression ratio 16.5; piston bowl shape - dished piston; number of fuel injector holes -3 ; initial fuel delivery starting $-25 \pm 1^{0}$ before top dead center; needle valve lifting pressure for all injectors $-17.5 \pm 0.5 \mathrm{MPa}$.

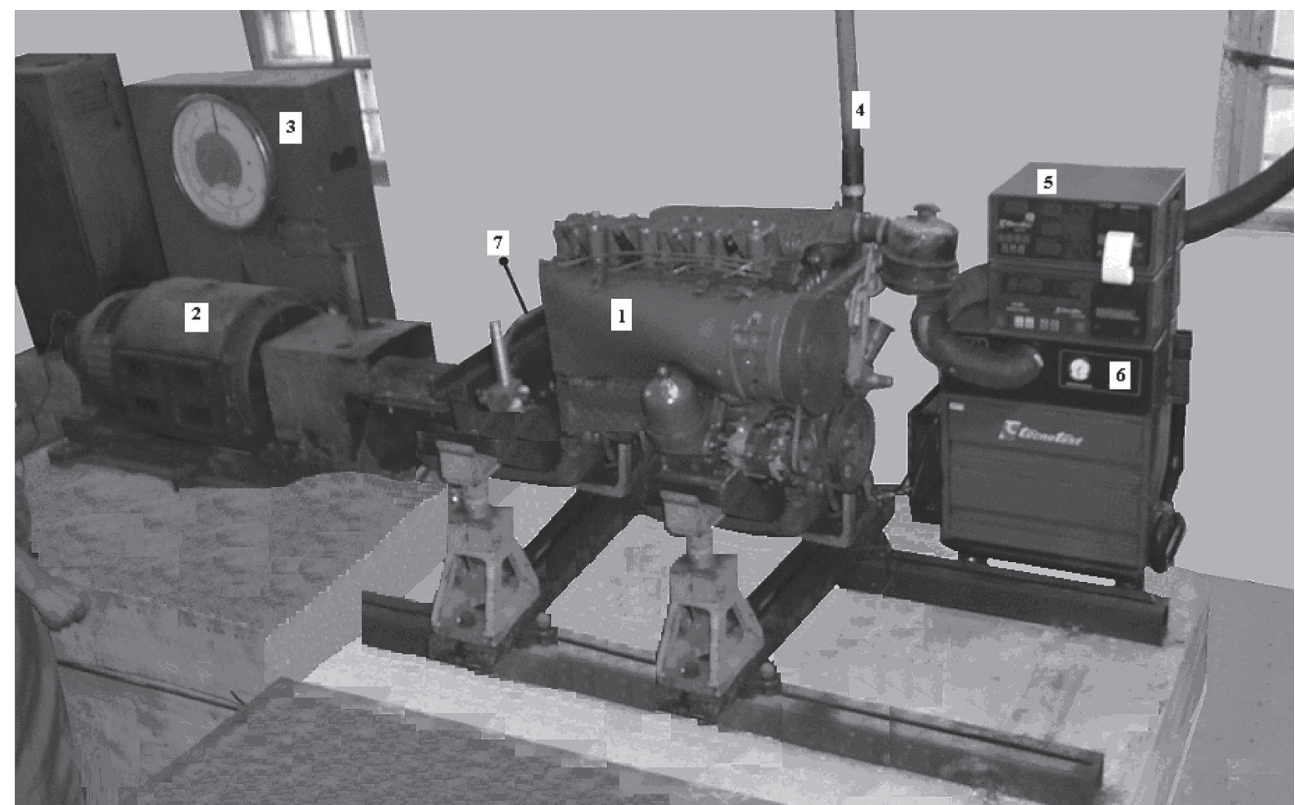

Fig. 2. Engine test bench: 1 - diesel engine D-144; 2 - asynchronous generator AKB-82-4UZ; 3 - engine load measuring device; 4 - tailpipe; 5 - exhaust gas analyzer Technotest 481; 6 - Smoke-meter Technotest 490; 7 - load change lever

D-144 torque measured via dynamometer with $\pm 2 \%$ accuracy. The revolution frequency of the crankshaft measured with a digital tachometer Tessa-1 (accuracy: $\pm 1 \%$ ) and duration of the every single test controlled with the help of second-meter SDS (accuracy: $\pm 0.2 \mathrm{~s}$ ).

\subsubsection{Portable emission analyzers}

Portable emission analyzers of gases manufactured by Instruments Techno Test Inc., models Technotest 481 (CO: 0-9.99\%, accuracy: $\pm 0.01 \%$; HC: $0-1995 \mathrm{ppm}$, accuracy: $\pm 2 \%$ ) and Technotest 490 (smoke opacity: $0-100 \%$, accuracy: $\pm 0.2 \%$ ) were used. Before carrying out of 
the experiments Technotest equipment was calibrated at State Metrology Service, established under the resolution of the Government of Republic of Lithuania. The level of nitrogen oxides was measured using an analyzer manufactured by Bacharach Inc., model PCA-65 $\left(\mathrm{NO}_{\mathrm{X}}\right.$ : 0-1000ppm; accuracy: $\pm 2 \%$ ).

\subsection{Promotion of investment-based activity}

Economical calculations and arrived suggestions concerning utilization of the motor biofuels in generation of the combined heat and power were obtained following Law on Energy of the Republic of Lithuania, Department of Statistics to the Government of the Republic of Lithuania (2009), Goebel et al. (1998), Fischer (2006), Beihong and Weiding (2006), Berta et al. (2006), Schneider (2006), Štreimikienė and Pareigis (2007), and Štreimikienė and Klevas (2007).

\section{Results and discussion}

\subsection{Engine outputs}

The engine speed was kept constant at $1600 \mathrm{rpm}$. Medium $(0.325 \mathrm{MPa})$ and high load $(0.650 \mathrm{MPa})$ modes related to those, most often applied in cogeneration plants has been selected to discuss the results of engine brake test.

Fig. 3 shows the brake specific fuel consumption (BSFC) rates and emission measurement data for diesel fuel at the medium-load and high-load conditions. The same parameters for bio-based types of fuel were graphically presented as a percentage declination from the setted value for diesel fuel, i.e. 100\%. All points shown in Fig. 3 were the average of ten data points, obtained following an approved process optimization technique for establishment of the diesel engine exploitation parameters, described in detail by Raslavičius (2009).

Since calorific value of B100, B50/dB50 and rapeseed oil was lower than diesel fuel, the fuel consumption had to be higher to maintain the same brake power (Liubarskis and Raslavičius 2006; Raslavičius and Bazaras 2010a). There was a 14\% higher BSFC rates measured for the B100 than both, the fossil diesel fuel and dDF. Brake specific fuel consumption rates for rapeseed oil and $\mathrm{B} 50 / \mathrm{dB} 50$ blends seems to be increased for $6 \%$ and $7 \%$ respectively, while comparing to $\mathrm{DF} / \mathrm{dDF}$.

The thermal efficiency of the engine D-144 running at both loads for B50/dB50 blends was the same as for diesel fuel (Raslavičius 2009). This indicates that the engine's ability to convert chemical energy to mechanical energy is the same for mentioned fuels. Need to denote, that higher thermal efficiency for RME and Rapeseed oil can be attributed to the oxygen content in the fuel and the concomitant improvement in combustion. These advantages seem to be particularly pronounced under high-load, low-air conditions (intrinsic to stationary applications based cogeneration plants), as here biofuels enables reasonable combustion in spite of an insufficient oxygen supply.

Taking about the ability of B100 to compound fossil diesel we must admit that intersolubility of components in the B50/dB50 system was substantially high and show the optimal results (Raslavičius and Bazaras 2010b). Analogous results have been observed by other researches later overviewed by Mittelbach and Remschmidt (2004). 


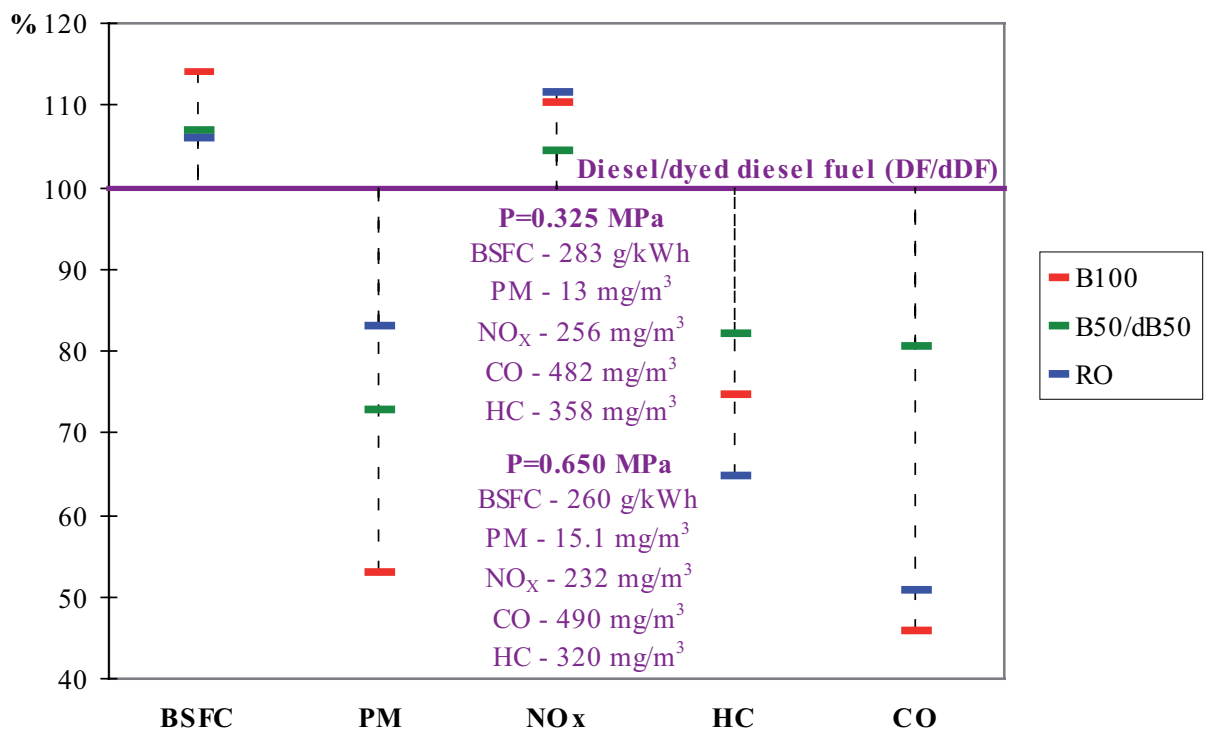

Fig. 3. Diesel engine performance characteristics-versus-type of fuel (obtained values for DF/dDF set as $100 \%$ )

The combustion of hydrocarbon fuel $(\mathrm{DF} / \mathrm{dDF})$ removes $\mathrm{O}_{2}$ from the atmosphere and releases equivalent amount of $\mathrm{H}_{2} \mathrm{O}$ and $\mathrm{CO}_{2}$ always with trace amounts of numerous other compounds including hydrocarbons $\left(\mathrm{CH}_{4}, \mathrm{C}_{2} \mathrm{H}_{2}, \mathrm{C}_{2} \mathrm{H}_{6}, \mathrm{C}_{2} \mathrm{H}_{8}, \mathrm{C}_{6} \mathrm{H}_{6}, \mathrm{CH}_{2}, \mathrm{CHO}\right.$, ...etc.), carbon monoxide $(\mathrm{CO})$, nitrogen oxides $\left(\mathrm{NO}, \mathrm{N}_{2} \mathrm{O}, \mathrm{NO}_{2}\right)$ and particles.

The results of the selected engine particulate matter (PM) emission level subjected to the type of fuel and load performance demonstrated in the Fig. 3. The obtained data differ widely depending on the tested fuels. The significant decrease in PM for biological origin based combustible compounds fuelled engine is explained by the oxygen content of the fuel. It enhances the oxygen availability within the cylinder during combustion and thus reduces pyrolysis of unburned and partly burnt compounds, which would lead formation of soot. In general, total particulate matter emissions from B100 and rapeseed oil combustion was lower than that for conventional diesel (DF/dDF), in $47 \%$ and $17 \%$ respectively.

All three groups of fuels, the fossil diesels, the B50/dB50 blends, and the rapeseed oil were significantly different from each other. The B50/dB50 had a $27 \%$ reduction in PM compared to DF/dDF. Exploitation parameters of diesel engine at high-load mode featured a decreased level of nitrogen oxides in $9.4 \%$ in comparison to the measured at $0.325 \mathrm{MPa}$. As a matter of fact, that motor biofuels-powered CHP plants emit lesser quantities of $\mathrm{NO}_{\mathrm{X}}$ at peak load condition comparing to smaller outputs of power and heat.

Unburned hydrocarbons, PM and NO are examples of primary pollutants. Nitrogen dioxide, which is emitted directly from exhaust, is formed in the atmosphere photochemically from NO. Although most early analytical and experimental studies focused on NO formation, more information now exists on $\mathrm{NO}_{2}$ and the conditions under which it is likely to form in combustion systems (Glassman and Yetter 2008). Some measurements in internal 
combustion engines have shown large amounts of $\mathrm{NO}_{2}$, which would be expected under the operation conditions. As the important effect of temperature on NO formation is discussed by many researchers, it is useful to remember that flame structure can play a most significant role in determining the overall $\mathrm{NO}_{\mathrm{X}}$ emitted. Ideally, the $\mathrm{NO}$ formation should peak at the stoichiometric value and decline on both the fuel-rich and fuel-lean regions of combustion chamber, just as the temperature does (Glassman and Yetter 2008). Actually, because of kinetic effects, the peak is found somewhat on the oxygen-rich (typical for biofuels) side of stoichiometric. Obtained level of $\mathrm{NO}_{\mathrm{X}}$ emissions (Fig. 3) for all tested pure biofuels (B100 and $\mathrm{RO}$ ) or compounded blends (B50/dB50) average from 5.1\% to $12.2 \%$ higher than those of diesel fuel, while discussing the medium-load $(0.325 \mathrm{MPa})$ and high-load $(0.650 \mathrm{MPa})$ conditions. Analysis of the test results shows, that the maximum $\mathrm{NO}_{\mathrm{X}}$ emissions increase proportionally with the mass percent of oxygen in the fuel. During replacement of the $\mathrm{DF} / \mathrm{dDF}(0.4 \%$ of oxygen $)$ by the $\mathrm{B} 100$ (10.7\% of oxygen), the $\mathrm{NO}_{\mathrm{X}}$ values increase by $10.4 \%$. Rapeseed oil explored even higher increase in emission of nitrogen oxides $-12.2 \%$.

In engine emission standards, hydrocarbons are commonly regulated as either total hydrocarbons or as non-methane hydrocarbons, with the latter category excluding methane $\left(\mathrm{CH}_{4}\right)$. Hydrocarbon emissions are greatly influenced by load, ambient conditions and fuelling system (Rakopoulos and Giakoumis 2009).

The plot shows significant difference in HC emissions between the motor biofuels and fossil diesel (Fig. 3). The rapeseed oil operation produced the lowest HC emission. According to Nwafor (2004), at high loading and combustion temperature (typical to cogeneration plant's operating at peak mode), the unheated RO better suits in the case of the reduction of HC emission compared to the heated rapeseed oil (because of the decreased fuel viscosity). However, contrary to $\mathrm{PM}, \mathrm{CO}$ and $\mathrm{NO}_{\mathrm{X}}$ that peak only during load increase or acceleration, diesel engine hydrocarbon emissions were noticed at the onset of deceleration or load decrease too (Rakopoulos and Giakoumis 2009).

Carbon monoxide (CO) is found in the combustion products of all carbonaceous fuels, and its concentration is dependent on the temperature and excess air. In fuel-rich regions of a flame, the CO levels are necessarily high since there is insufficient oxygen for complete combustion. Only if sufficient air is mixed with such gases at sufficiently high temperature the $\mathrm{CO}$ can be oxidized. Thus, imperfect mixing can allow carbon monoxide to escape from combustors that are operated at fuel-lean mixtures. In general, the replacement of pure DF by RME causes a decrease in emission level of carbon monoxide dramatically, by 55\% (Fig. 3). Must to admit, the emission of $\mathrm{CO}$ diminishes when operating high-speed diesel engine at overloaded-mode conditions. Under given testing condition $(0.325 \mathrm{MPa}$ and $0.625 \mathrm{MPa})$ the biggest carbon monoxide emission was generated by diesel fuel whereas pure RO exhibited by $49 \%$ lower emission. While compounding DF with biodiesel fuel in equal proportions (v/v), the mentioned above emission changes remain in good agreement with higher combustion efficiency obtained for pure motor biofuels.

\subsection{Economic buy-back rates}

Proposed CHP is an economically productive approach to reducing air pollutants through pollution prevention, whereas traditional pollution control achieved exclusively through flue 
gas treatment provides no profitable output and actually reduces efficiency and useful energy output. The main components of the small-scale cogeneration system are: a prime mover (internal combustion diesel engine), an electrical generator (driven from the prime mover), heat recovery system, control system, exhaust system, an acoustic enclosure.

The modulus of cogeneration plant (comprising of the mentioned above components) of the capacity of $340 \mathrm{~kW}$ has been selected (prices for: plant - 448500 LTL; building works 30000 LTL) to evaluate the economic feasibility to utilize motor biofuels in cogeneration output cycle under conditions in rural Lithuania. Combined heat and power potential has been evaluated to be $340 \mathrm{~kW}$ of electricity and $492.75 \mathrm{~kW}$ of thermal energy with 8500 hours of annual peak load time on district heat energy consumption produced on motor biofuels. The CHP potential was evaluated to be 2890 MWh electricity and 4188.4 MWh heat with 8500 hours of annual peak load time. Partial loads (medium- and small-sized) were not taken into account, reasoning on proposed application (discussed in Chapter 2.2.), where year-round demand for thermal energy exists.

Production costs for RME have not been estimated due to the fact that there are many big-sized enterprises in local in market able fully satisfy a demand for Lithuania as well as the wholesale prices cannot be diminished by farm-scaled plants.

\subsubsection{Borrowing capacity provided by the banking system}

To the extent that is practical, bank programs should lower financial and economic transaction costs to do implementation of biomass conversion projects easier realizable. It is recognized that the fixed costs of doing business are less easily absorbed by smaller firms than by large ones. Lithuanian banks aggregating activities to many borrowers having intent to apply any biomass as a renewable type of fuel. The long term bank credit for business purpose have time horizon of 7 years with the interest rate of $10 \%$ per year giving a vision to the project's development. Therefore, efforts to reduce bureaucratic procedures, enhance access to credit, eliminate unnecessarily restrictive labor practices, and expand the availability of market-related information will benefit the entry of the new CHP technologies adopted in rural Lithuania to a greater degree.

\subsubsection{Rapeseed oil production-based costing}

Activity-based costing provides an enhanced means for the owners of cogeneration plants to assess the cost-versus-benefits of such practice. For the technical-economic evaluation of using of rapeseed oil for combined heat and power production, we took oil-mill of $500 \mathrm{t}$ capacity. It is recommendable that the oil-mill must be founded on the cooperation basis.

A rapeseed yield of $1500 \mathrm{t}$ will yield approximately $500 \mathrm{t}$ of oil per annum. Expenses for rapeseed oil production are presented in Table 3. A cost price for rapeseed oil has been evaluated as the difference between total expenses and total earned incomes obtained for the sold oilcake to the stockbreeders.

With reference to Table 3, a prime cost for 1 tone of rapeseed oil comprises of 1523 LTL. Accordingly, $1 \mathrm{~kg}$ of RO comprises of 1.523 LTL or 1.39 LTL per liter. Estimated price is approx. 2.4 times lower than the wholesale price for conventional diesel fuel and about 35\% less than the price of dyed diesel used by farmers. 
Table 3. Cost price for ready production per annum (credit period)

\begin{tabular}{|c|c|c|c|}
\hline Expenditure & Amount & Cost (LTL/ supply) & Overall (thousand LTL/a) \\
\hline (1) Rapeseed, t & 1500 & 900 & 1350.000 \\
\hline (2) Electricity, MWh & 95 & 400 & 38.000 \\
\hline (3) Depreciation expenses: $10 \%$ & & 150100 & 36.450 \\
\hline $\begin{array}{l}\text { (4) Deduction for maintenance: } \\
\text { - rapeseed oil press: } 5 \% \\
\text { - other equipment: } 2 \%\end{array}$ & & $\begin{array}{c}37000 \\
114800\end{array}$ & $\begin{array}{l}1.850 \\
2.300\end{array}$ \\
\hline (5) Preparation and storage, $t$ & 1500 & 10 & 15.000 \\
\hline (6) Transportation & & & 5.300 \\
\hline (7) Expenses for factory, marketing, etc. & & & 62.800 \\
\hline (8) Total expenditure $(1)+(2)+\ldots+(7)$ & \multicolumn{3}{|c|}{1511.700} \\
\hline \multicolumn{4}{|l|}{ Incomes } \\
\hline (9) Rapeseed oilcake, t & 1000 & 750 & 750.000 \\
\hline Cost price (8)-(9) & 500 & 1523 & 761.700 \\
\hline
\end{tabular}

\subsubsection{Setting of prices for thermal energy}

The rates charged to a building by a combined heat and power production plant developer or operator for electricity and thermal outputs typically include factors for capital recovery, depreciation expenses, maintenance, incidental expenses, non-energy expenses and fuel (rapeseed methyl ester, rapeseed oil, DF/dDF and B50/dB50). In many cases electricity generated by the CHP plant is sold to the grid or an external customer. Both thermal and electrical outputs of the CHP plant are used within the design-building.

The economic attractiveness of cogeneration plants for consumers largely rests on a number of regulatory advantages. These include the exemption from electricity taxation, the payment of a bonus for generated electricity fed into the grid and the avoidance of concession levies and grid charges for electricity generated on-site. Unfortunately, the mentioned above initiatives are at the initial stage of development in Lithuania.

In fact, CHP plants working on rapeseed oil have the biggest potential of contribution to the sustainable development of rural Lithuania (see Table 4). It is a cost-effective method of generating electricity and thermal energy with an estimated high potential. It can be economically viable for the end-user even without any form of subsidy.

The most significant barrier to the use of B100 for stationary energy generation is represented by economic issues: the biodiesel cost is the most critical element in a decentralized and liberalized energy market, where fossil fuel prices do not act in favor of RME, unless externalities are not taken into account. Analogous could be said about the compounding fossil diesel with rapeseed oil methyl ester to obtain B50. Taking into account an expectative increase of prices for fuel oil in near future, the biodiesel can be utilized only as a compounding additive to the dyed diesel fuel, if no subsidies to be foreseen. 
Table 4. CHP calculation methodology

\begin{tabular}{|c|c|c|c|c|c|c|}
\hline 1. Expenditure & DF & dDF & B100 & B50 & dB50 & RO \\
\hline (a) Depreciation expenses, LTL/a & \multicolumn{6}{|c|}{116200} \\
\hline (b) Maintenance, LTL/a & \multicolumn{6}{|c|}{24000} \\
\hline (c) Incidental expenses, LTL/a & \multicolumn{6}{|c|}{20000} \\
\hline $\begin{array}{l}\text { (d) Fuel, LTL/a: } \\
\text { - working hours, ha/a } \\
\text { - consumption, l/h } \\
\text { - market cost, LTL/l }\end{array}$ & $\begin{array}{c}2273920 \\
8500 \\
76.0 \\
3.52\end{array}$ & $\begin{array}{c}1627920 \\
8500 \\
76.0 \\
2.52\end{array}$ & $\begin{array}{c}2793304 \\
8500 \\
87.4 \\
3.76^{\star}\end{array}$ & $\begin{array}{c}2540174 \\
8500 \\
82.1 \\
3.64\end{array}$ & $\begin{array}{c}2191249 \\
8500 \\
82.1 \\
3.14\end{array}$ & $\begin{array}{c}942837 \\
8500 \\
79.8 \\
1.390\end{array}$ \\
\hline $\begin{array}{l}\text { (e) Total expenditure }(\mathrm{a})+\ldots+(\mathrm{d}) \\
\text { LTL/a }\end{array}$ & 2434120 & 1788120 & 2953504 & 2700374 & 2191249 & 1103037 \\
\hline \multicolumn{7}{|l|}{ 2. Incomes } \\
\hline "Green electricity" output, kWh/a & \multicolumn{6}{|c|}{2890000} \\
\hline $\begin{array}{l}\text { Price for "Green electricity" sold to } \\
\text { the grid, LTL/kWh }\end{array}$ & \multicolumn{6}{|c|}{0.22} \\
\hline $\begin{array}{l}\text { (f) Incomes from "Green electric- } \\
\text { ity" produced, LTL/a }\end{array}$ & \multicolumn{6}{|c|}{635800} \\
\hline (g) Deficit spending (e)-(f), LTL/a & 1798320 & 1152320 & 2317704 & 2064574 & 1555449 & 467237 \\
\hline \multicolumn{7}{|l|}{ 4. Thermal output ("free") } \\
\hline (h) Thermal energy output, kWh/a & \multicolumn{6}{|c|}{4188406} \\
\hline $\begin{array}{l}\text { Cost price for thermal energy pro- } \\
\text { duced }(\mathrm{g}) /(\mathrm{h}), \mathrm{LTL} / \mathrm{kWh}\end{array}$ & 0.430 & 0.275 & 0.553 & 0.493 & 0.371 & 0.111 \\
\hline
\end{tabular}

${ }^{*}$ wholesale price + profit mark-up on cost of $30 \%$

\section{Conclusions}

Key figures of energy generation opportunity in motor biofuels-driven CHP plant are costs. They were thus analyzed in detail for every option discussed in depth. As a consequence, some of the motor biofuels in cogeneration output cycle offer to consumers the strategic advantage of moderate oil prices.

A wide range of crops in rural Lithuania can be used for plant oil, but in reality only rapeseed oil is being used recently. The production path is relatively simple as it consists simply in growing and harvesting the seeds, pressing the oil at low temperature and filtering the final product to remove impurities. Thus, the production technology can be applied at almost any scale. Also, in comparison to large agrarian counties, rapeseed oil production for domestic purposes in rural Lithuania is not constrained by availability of agricultural land in terms of total extent of usable land; in terms of crop rotation needs (rape can only grow every 5-7 years on the same land); in terms of competitions with other crops and because of the Blair House Agreement limiting the area for oilseed productions in EU-27 countries (as a global policy). 
In order to promote the development and growth of different motor biofuels (rapeseed oil methyl ester, B50/dB50, etc.) for combined heat and power production, the institutional and regulatory barriers, which are biased against them, should be partially reduced. The key policy areas are in input markets (capital, technology, production inputs), output markets (pricing, access to market information), and regulations (tax, tariffs).

Following conclusions can be drawn from the analysis presented in the paper:

- The total investment costs of the project amounted to about 478500 LTL.

- Taking 8500 full load operating hours per year, a funding rate of $0 \%$, a payback time of 7 years and an interest rate of $10 \%$ per annum into account, the thermal energy costs calculated for $340 \mathrm{~kW}$ diesel engine-driven CHP plant running on rapeseed oil amount to approximately $0.111 \mathrm{LTL} / \mathrm{kWh}$. This price lies under the established one by the centralized energy suppliers.

- In comparison to diesel fuel, RO exhibited lower emissions of the hazardous pollutants: CO (-49\%), PM (-17\%) and HC (-34\%). Hence, rapeseed oil distinguishes for increased emission of nitrogen oxides $(+12.2 \%)$.

- From the viewpoint of fuel economy, rapeseed oil demonstrated the lowest BSFC values comparing to biodiesel fuels (B100, B50/dB50).

\section{References}

Agarwal, S.; Wong, J. 1996. Competitiveness and marketability of vegetable oils, oilmeals, and plant equipment for processing of oilseeds and oils in the Baltic States. MA TRIC Working Paper 96-MWP 1 [online], [cited 21 Nov. 2009]. Available from Internet: <http://www.card.iastate.edu/publications/ DBS/PDFFiles/96mwp1.pdf>.

Beihong, Z.; Weiding, L. 2006. An optimal sizing method for cogeneration plants, Energy and Buildings 38(3): 189-195. doi:10.1016/j.enbuild.2005.05.009

Berta, G.-L.; Prato, A. P.; Garbarino, L. 2006. Design criteria for distributed cogeneration plants, Energy 31(10-11): 1403-1416. doi:10.1016/j.energy.2005.05.022

Bugge, J. 2001. Rape seed oil for transport 2: Agriculture and energy / the energy purpose market for rapeseed oil. Nordic Folkencenter for Renewable Energy 2000: report in Danish [online], [cited 21 Nov. 2009]. Available from Internet: <http://www.folkecenter.dk/plant-oil/publications/agriculture_and_energy.pdf $>$.

CEERE. 2009. Center of Energy Efficiency and Renewable Energy: Combined Heat \& Power [online], [cited 21 Nov. 2009]. Available from Internet: <http://www.ceere.org/iac/iac_combined.html >.

Department of Statistics to the Government of the Republic of Lithuania [online]. 2008. [Cited 12 Nov. 2009]. Available from Internet: < http://www.stat.gov.lt/en>.

Department of Statistics to the Government of the Republic of Lithuania [online]. 2009. [Cited 3 May 2010]. Available from Internet: <http://www.stat.gov.lt/en>.

Fischer, C. 2006. From consumers to operators: the role of micro CHP users, in Pehnt, M.; Cames, M.; Fischer, C.; Praetorius, B.; Schneider, L.; Schumacher, K.; Vob, J.-P. (Editors). Microcogeneration. Towards decentralized energy systems. Berlin: Springer Berlin Heidelberg, 117-143.

Garcia, J. L.; De la Plaza, S.; Navas, L. M.; Benavente, R. M.; Luna, L. 1998. Evaluation of the feasibility of alternative energy sources for greenhouse heating, Journal of Agricultural Engineering Research 69(2): 107-114. doi:10.1006/jaer.1997.0228

Ghosal, M. K.; Tiwari, G. N. 2004. Mathematical modeling for greenhouse heating by using thermal curtain and geothermal energy, Solar Energy 76(5): 603-613. doi:10.1016/j.solener.2003.12.004 
Giniger, M. S.; Mears, D. R. 1984. Industry Cogeneration of heat and electricity for greenhouse use, in Proc. of the $3^{\text {rd }}$ International Symposium on Energy in Protected Cultivation. Available from Internet: $<$ http://www.actahort.org/books/148/>.

Glassman, I.; Yetter, R. A. 2008. Combustion. $4^{\text {th }}$ ed. Amsterdam: Academic Press.

Goebel, D. J.; Marshall, G. W.; Locander, W. B. 1998. Activity-based costing: accounting for a market orientation, Industrial Marketing Management 24(6): 497-510. doi:10.1016/S0019-8501(98)00005-4

Jenkins, B. M. 1985. Effective alternative greenhouse heating systems, California Agriculture: 5-7.

Kaltschmitt, M.; Streicher, W.; Wiese, A. 2007. Renewable energy: Technology, economics and environment. Berlin and New York: Springer.

Liubarskis, V.; Raslavičius, L. 2003. Производство и применение биодизельного топлива в Литве [Biodiesel production and consumption in Lithuania], in Proc. of the $2^{\text {nd }}$ International Conference Agrarian Energetics of the XXI Century [Аграрная энергетика в XXI-м столетии]. Minsk, 27-28 November 2003. Selected Papers, Ed. V. S. Kotov, V. I. Rusan, V. V. Kuzmich and S. G. Tereshkova. Minsk: Technoprint, 25-27.

Liubarskis, V.; Raslavičius, L. 2006. Исследование экологических и энергетических показателей применения мультикомпонентной топливной смеси в дизельных двигателях [Research into ecological and energy characteristics of the diesel engines running on multi-component fuel blends], in Proc. of the $22^{\text {nd }}$ Scientific Conference of the CIS Countries - Disperse Systems, Odessa, 18-22 September. Thesis report, Ed. T. M. Zabanova. Odessa: Astroprint, 226-226.

LST EN 590:2009 Automotive fuels - Diesel - Requirements and test methods.

LST EN 14214:2009 Automotive fuels - Fatty acid methyl esters (FAME) for Diesel engines - Requirements and test methods.

Mittelbach, M.; Remschmidt, C. 2004. Biodiesel: a comprehensive handbook. Vienna: Boersedruck Ges.m.b.H.

Nwafor, O. M. I. 2004. Emission characteristics of diesel engine running on vegetable oil with elevated fuel inlet temperature, Biomass and Bioenergy 27(5): 507-511. doi:10.1016/j.biombioe.2004.02.004

Rakopoulos, C. D.; Giakoumis, E. G. 2009. Diesel engine transient operation: Principles of operation and simulation analysis. London: Springer.

Raslavičius, L. 2009. Research into three-component combustible mixture application for fuelling diesel engines: Summary of Ph.D. thesis. Kaunas: Technologija.

Raslavičius, L.; Bazaras, Ž. 2010a. Variations in oxygenated blend composition to meet energy and combustion characteristics very similar to the diesel fuel, Fuel Processing Technology 91(9): 1049-1054. doi:10.1016/j.fuproc.2010.03.011

Raslavičius, L.; Bazaras, Ž. 2010b. The possibility of increasing the quantity of oxygenates in fuel blends with no diesel engine modifications, Transport 25(1): 81-88. doi:10.3846/transport.2010.11

Raslavičius, L.; Strakšas, A. 2010. Environmental-economic analysis of engine driven CHP plant running on liquid biofuels, in Proc. of the $5^{\text {th }}$ International Conference Intelligent Technologies in Logistics and Mechatronics Systems (ITELMS), Panevėžys, 3-4 June 2010. Selected papers, Ed. Ž. Bazaras and V. Kleiza. Kaunas: Technologija, 43-47.

Rasburskis, N.; Gudzinskas, J.; Gylys, J. 2006. Combined heat and power production: socio-economic and sustainable development aspects, Journal of Civil Engineering and Management 12(1): 29-36.

Schneider, L. 2006. Economics of micro-cogeneration, in Pehnt, M.; Cames, M.; Fischer, C.; Praetorius, B.; Schneider, L.; Schumacher, K.; Voß, J.-P. (Editors). Micro-cogeneration: Towards decentralized energy systems. Berlin: Springer Berlin Heidelberg, 67-86.

Sörensen, B. 2004. Renewable Energy: Its physics, engineering, use, environmental impacts, economy and planning aspects. London: Elsevier Academic Press. 
Survilienè, E. 2001. Phytosanitary state and urgent problems of greenhouse vegetable protection in Lithuania, in Proceedings of the $9^{\text {th }}$ International Conference of Horticulture, Lednice, 3-6 September, 2001. Selected papers, Ed. P. Salaš 1(2): 392-397.

Štreimikiene, D.; Pareigis, R. 2007. Promotion of use of alternative energy sources in Lithuania, Technological and Economic Development of Economy 13(2): 159-169.

Štreimikiene, D.; Klevas, V. 2007. Promotion of renewable energy in Baltic States, Renewable and Sustainable Energy Reviews 11(4): 672-687. doi:10.1016/j.rser.2005.03.004

UNEP: Division of Technology, Industry and Economics [online]. 2008. Energy and Ozon Action Unit: Cogeneration. [cited 15 May 2010]. Available from Internet: <http://www.unep.fr/energy/information/publications/factsheets/pdf/cogeneration.pdf $>$.

Von Zabeltitz, C. 1994. Effective use of renewable energies for greenhouse heating, Renewable Energy 5(1-4): 479-485. doi:10.1016/0960-1481(94)90419-7

\section{MOTORINIAIS BIODEGALAIS KŪRENAMOS KOGENERACINĖS JĖGAINĖS - ŽINGSNIS DARNAUS LIETUVOS KAIMO REGIONŲ VYSTYMOSI LINK}

\section{Raslavičius, A. Strakšas}

Santrauka. Straipsnio tikslas - atkreipti dèmesị ị potencialiai gaunamą naudą eksploatuojant mažos galios kombinuotos šilumos ir elektros gamybos jègaines, esant argumentuotam degalų tipo bei pagamintos energijos realizavimo srities pasirinkimui. Atlikta analizè gali būti informacine priemone, skatinančia stambių ūkių bei pramoninių šiltnamių savininkus diegti mažos galios kogeneracines jègaines, naudojančias biologinès kilmės skystuosius degalus. Pagrindinių veiksnių, darančių ịtaką sẻkmingiems veiklos rezultatams, ịvardijimas ir analizè yra pirmieji žingsniai, užtikrintys nuoseklesnę Europos Komisijos bei atsakingų šalies institucijų strategiją dèl mažos galios kogeneracinių jẻgainių ateities perspektyvų šalyje bei darnaus Lietuvos kaimo regionų vystymosi. Šiam tikslui pasiekti straipsnyje pateikiami biodyzelino, jo mišinių su mineraliniu dyzelinu bei rapsų aliejaus taikymo kombinuotos šilumos ir elektros gamybai techniniai, aplinkosauginiai ir ekonominiai aspektai, kurie turètų praplèsti mokslinių diskusijų apie darnaus šalies vystymosi naujas kryptis ir perspektyvas temą.

Reikšminiai žodžiai: motoriniai biodegalai, kogeneracinè jẻgainė, Lietuvos kaimo regionai, kombinuota šiluma ir elektra, pirmosios kartos biodegalai, energijos tiekimas.

Laurencas RASLAVIČIUS. Doctor of Technological Sciences, Innovations engineer for biofuel energy sector at UAB "Axis Technologies" - a branch enterprise of "Axis Industries" - the largest group of companies in Lithuania dealing with industrial and energy sector projects. Nearly a decade (2001-2010) of scientific worker activity was spent at Lithuanian University of Agriculture, Institute of Agro-Engineering (LUA IAE) with an emphasis in renewable energy, biogas, liquid and solid biofuels, internal combustion engines, combined heat and power, combustion, energy policy. Since 2001, participated in the following research projects concerning renewable energy:

- Ecological and energy saving technologies in agriculture (2003; Sponsored by EC);

- Research into exploitation characteristics of diesel engine fuelled with implemented type of fuel biodiesel (Biodiesel implementation programme 2003; Sponsored by Ministry of Agriculture of the Republic of Lithuania);

- The possibilities to use liquid biofuels in agricultural technique and municipal transport (2004; Sponsored by EC);

- Optimization of methods for biofuel production and utilization (2003-2005; Sponsored by IAE LUA);

- Development of plant biomass-to-energy technologies: cultivation, preparation and conversion (2005-2006; Sponsored by Ministry of Agriculture of the Republic of Lithuania and Lithuania State Science and Studies Foundation); 
- Energy and environmental assessment of the biogas-from-biomass production (2008; Sponsored by IAE LUA);

- Bioenergy in Ukraine - possibilities of rural development and opportunities for local communities (2009-2010; Sponsored by Ministry of Agriculture of the Republic of Lithuania).

Anicetas STRAKŠAS. Doctor of Technical Sciences, senior research worker at Lithuanian University of Agriculture, Institute of Agro-Engineering (LUA IAE) and lecturer of LUA. 25 years of his scientific career was dedicated to research studies into various harvesting technologies for grain and leguminous crops, perennial grasses, linseed flax and other agricultural plants. His name is among the very first researchers in Lithuania, who initiated and implemented a mass production of stripping-thrashing technology intended for grain harvesting. Recently, research and scientific activity of A. Strakšas is directly connected with questions related to rapeseed cultivation and harvesting, oil pressing and using it as a fuel for internal combustion engines-driven CHP plants. 